\title{
Orientación normativa en diccionarios monolingües de inglés como lengua extranjera ${ }^{1}$
}

\section{Language Guidance in English Learner's Dictionaries}

\author{
Félix Bugueño Miranda² \\ Laura Campos de Borba $^{3}$
}

\author{
Citation/ Para citar este Artículo: Bugueño Miranda, F. y Campos de Borba, L. (2020). Orientación normativa en diccionarios monolingües de \\ inglés como lengua extranjera. Colomb. Appl. Linguistic. J., 22(2), pp. 157-168. \\ Received: 8-Nov.-2019 / Accepted: 3-Nov.-2020 \\ DOI: https://doi.org/10.14483/22487085.15528
}

\section{Resumen}

La orientación en el uso de la lengua es una dimensión inherente al aprendizaje; a pesar de ello, la lingüística anglosajona nunca le ha prestado mayor atención a esta dimensión. Paradojalmente, los diccionarios monolingües de inglés como lengua extranjera se caracterizan por ofrecer una orientación ostensiva. En el marco de un proyecto de un diccionario de dudas para estudiantes de español brasileños, decidimos investigar cómo se realiza la orientación en el uso de la lengua al seno de la tradición de la lexicografía monolingüe de aprendientes de inglés, que representa siempre los mayores avances en materia de enseñanza de lenguas extranjeras. El objetivo de este trabajo fue analizar la clase de orientación que los diccionarios monolingües de inglés como lengua extranjera presentan. Como metodología, establecimos una red de distinciones basada en la oposición entre descripción y prescripción y, subsecuentemente, entre prescribir un uso determinado o prohibirlo. Nuestros resultados demuestran que la lexicografía anglosajona emplea todo este espectro de posibilidades de orientación de una manera particularmente eficiente y multidimensional. Pudimos concluir que la dicotomía descripción-prescripción no se sustenta en la lexicografía monolingüe de aprendientes de inglés como lengua extranjera. En última instancia la búsqueda por orientación obedece a un anhelo del aprendiente.

Palabras clave: diccionarios monolingües de inglés como lengua extranjera, lengua inglesa, orientación normativa, uso de la lengua

\footnotetext{
Abstract

Guidance in language use is an inherent aspect of language learning. Nonetheless, English linguistics has not paid attention to this dimension. Paradoxically, English learner's dictionaries are characterized by offering evident guidance on language use. In the framework of a research project to compile a dictionary of Brazilian learners' doubts about the Spanish language, we decided to investigate the English language lexicographic tradition, whose learner's dictionaries lead substantial advances in foreign language teaching. This paper aimed to analyse how English learner's dictionaries provide instruction on language use. The methodology consists of

1 Este artículo se encuadra en el marco de un proyecto de investigación intitulado "Diccionario de dudas y dificultades de español para brasileños", desarrollado en la Universidade Federal do Rio Grande do Sul. El segundo autor recibe una beca de doctorado de CAPES (Brasil), Código de Financiamiento 001.

2 Universidade Federal do Rio Grande do Sul (Brasil). Correo electrónico: felixv@uol.com.br. ORCID (D): https://orcid.org/0000-00016234-101X

3 Universidade Federal do Rio Grande do Sul (Brasil). Correo electrónico: lauracborba@ hotmail.com. ORCID (D): https://orcid.org/00000001-5316-9334
} 
the application of a set of formal distinctions based on the opposition between description and prescription, and, subsequently, prescribing a certain language use or forbidding it. Our results show that the English language lexicography applies this whole array of guidance techniques on a particularly efficient and multidimensional way. We could conclude that the description-prescription dichotomy does not sustain itself in English learner's lexicography. Ultimately, the act of looking for guidance about the English language in use reflects the learner's inherent desire for instructions.

Keywords: English learner's dictionaries, English language, language guidance, language in use

\section{Introducción}

En el marco de un proyecto de investigación sobre la compilación de una guía de dudas lingüísticas para aprendientes de español brasileños, nos encontramos con una situación hasta cierto punto paradójica. Por un lado, el hablante nativo de español cuenta con una respetable cantidad de materiales bibliográficos para resolver sus dudas. Es fundamental destacar que es ese hablante el que reclama orientación. En el ámbito de la enseñanza de español como lengua extranjera, la situación es completamente diferente. La literatura deja de manifiesto, particularmente en la enseñanza de español en Brasil, que hay una desatención en lo que respecta a la orientación en el uso de la lengua. En ese sentido, dos son los instrumentos canónicos para procurar dicha orientación: la gramática y el diccionario.

Con relación a las gramáticas para aprendientes de español, son muy pocas las que orientan explícitamente en relación con los usos de la lengua, lamentablemente. La otra opción está constituida por los diccionarios monolingües de aprendientes, ${ }^{4}$ que, desafortunadamente, son numéricamente escasos y cualitativamente deficientes.

4 No existe en la literatura de lengua española sobre lexicografía un equivalente suficientemente consagrado para el término inglés learner's dictionary. Para efecto de este trabajo, se escogió la expresión diccionario monolingüe de aprendientes.
A raíz de dichas particularidades, decidimos investigar cómo se orienta el uso de la lengua en una tradición tan sólida como lo es la enseñanza de inglés como lengua extranjera/segunda; y, para nuestra sorpresa, en este caso las relaciones se invierten. Aparentemente, a la lingüística anglosajona parece no importarle mucho la orientación cuando se trata del hablante nativo; no así cuando se trata del aprendiente, ya que para este público los diccionarios monolingües de inglés como lengua extranjera ofrecen una orientación explícita y que perfectamente puede calificarse de generosa.

En función de lo expuesto, el objetivo de este trabajo es analizar las modalidades de orientación que la lexicografía monolingüe de aprendientes de inglés ofrece.

\section{La orientación en el uso de la lengua}

Zanatta (2017) reconoce como rasgo definidor de la actividad lingüística la existencia de un "anhelo normativo" (anseio normativo). Para que se entienda mejor ese fenómeno, es conveniente recordar que una comunidad lingüística reconoce y ejecuta en sí misma una manera particular de hablar. A tal manera particular Coseriu (1992) la llama norma, que se entiende como lo que es normal y frecuente para este grupo de individuos. Nos referiremos a esa norma como norma real. En una lengua hay una diversidad de normas reales que se diferencian unas de otras por particularidades en los ejes diatópico (lugar), diacrónico (tiempo) y diafásico-diastrático (situación de uso y extracto sociocultural), entre otros aspectos. Paralelamente, en la propia comunidad lingüística existe una necesidad de contar con una norma de referencia para que los hablantes se expresen en determinadas circunstancias; así, el anhelo normativo corresponde a esa necesidad. Con el objetivo de satisfacerla, la comunidad promueve a partir del conjunto de normas reales un segundo tipo de norma que sirve de referencia en situaciones en las que se juzgue pertinente usar una modalidad expresiva más elaborada. A esta segunda norma, fruto de la realización de una norma real específica, se la denomina norma ideal. 
El hecho de establecer una norma ideal acarrea dos problemas para una comunidad lingüística: quién desempeñará la tarea de establecer dicha norma y dónde ir a buscarla. En el ámbito del español, la comunidad hispánica le atribuye hace cuatro siglos esta función a la Real Academia Española (RAE). Desde su fundación en el siglo XVII, la labor de los académicos es colectiva y tiene el propósito de que sus decisiones sean producto del consenso, respetando el principio de que la lengua es de todos y no "propiedad" de un grupo particular. En ese sentido los hispanohablantes en general se sienten reflejados en la norma ideal que propone la RAE. Por otro lado, no todas las comunidades lingüísticas reconocen una norma común y eso tiene consecuencias, por ejemplo, a la hora de juzgar hechos lingüísticos en los estudios anglosajones sobre el error. Respecto a este tema Nava (2017) ofrece aclaradoras explicaciones.

En resumen, se puede constatar que es posible satisfacer el anhelo normativo de los hablantes de una comunidad lingüística desde que exista una entidad que oriente esta tarea, sea oficial (como la RAE) o creada de facto, como el caso del francés, que delega la orientación en el uso de la lengua a la iniciativa editorial privada, como Le Robert y Larousse.

En una situación completamente diferente se encuentra la lengua inglesa. En primer lugar, no hay por consenso ni tampoco de facto una institución que oriente el uso de la lengua (Crystal, 2003a, p. 4). Falta, por lo tanto, una autoridad de referencia; asimismo, tampoco hay un consenso respecto a qué norma podría servir de orientación. Con relación a este aspecto, Nava (2017, p. 86) comenta que "las gramáticas de cuarta y quinta tradiciones gramatológicas inglesas [i.e. gramáticas presuntamente descriptivas] ya han asumido que las normas del inglés estándar se basan en los hablantes nativos de los países BANA". En cambio, y distinto de lo que acontece con el español, Nava (2017) no comenta si existe la posibilidad de que a partir de estas normas reales del inglés se pueda establecer una invariante común. De hecho, Crystal (2003b, p. 149) ya advertía que "hay más señales de diferenciación gramatical de lo que generalmente se sugiere". Dicho en otros términos, Nava (2017) parece insinuar que el inglés propende más a una situación de aceptación de los hechos de norma legítimos en algunos puntos del diasistema del inglés (pero no en todos) que a una situación de una norma paninglesa; esto es lo que Moreno de Alba (1993) llama de ejemplaridad.

Conforme a lo que se ha comentado ad supra, en su síntesis historiográfica de la gramaticología inglesa, Nava (2017) sugiere que actualmente las obras gramaticales de esta tradición pretenden describir lo que se podría denominar norma real de la lengua inglesa con atención a la variación diatópica (por la mención a los países BANA). Obedeciendo a una tradición consolidada en la lingüística, en esta afirmación subyace que la explicitación de la norma real implica apenas su descripción en total oposición a la prescripción, que constituye el ámbito de la norma ideal. Los esfuerzos de la lingüística inglesa por evitar la prescripción se notan en la siguiente definición de gramática del Oxford Concise Dictionary of Linguistics (OxLing, 1997): "cualquier descripción sistemática de la estructura de una lengua; los patrones que describe [...]" (OxLing, 1997, s.v. grammar).

Porlo que se refierea la prescripción, es pertinente hacer dos observaciones que influyen directamente sobre la noción de corrección y, consecuentemente, de error. En primer lugar, Moreno de Alba (1992, p. 8) afirma que hay una estrecha relación entre la norma real y la norma ideal; de acuerdo con lo que se ha mencionado anteriormente, esta relación no es antitética en la medida en que la norma ideal (orientación en el uso de la lengua) es previamente norma real (uso). Los miembros de una comunidad consideran esa norma ideal como un modelo que se puede usar como referencia en situaciones de comunicación que requieren un desempeño lingüístico esmerado, según se comentó ya. Además, y ampliando el ámbito de una observación de Alarcos Llorach (1994, p. 18) respecto a la normatividad intrínseca de las gramáticas, se puede afirmar que, aunque se definan de forma patente como estrictamente descriptivos, un compendio gramatical o un diccionario terminan, de facto, ejerciendo una función normativa. La normatividad existe implícitamente en la medida en que estas clases de obras exponen o proponen una norma 
y no otra; además, en muchos casos es la propia comunidad la que les confiere esa autoridad, particularmente en el caso de los diccionarios. Debido a eso, la distinción entre norma real y norma ideal, o si se quiere, entre descripción y prescripción, no existe en la práctica de forma tan dicotómica en diccionarios y gramáticas. En lo que respecta a los diccionarios monolingües de inglés como lengua extranjera y, como se demostrará más adelante, es común encontrar explícitamente orientaciones de tipo normativo en esta clase de obras.

En suma, es evidente que el anhelo normativo forma parte de la actividad lingüística de los hablantes; también se puede afirmar que hay cómo satisfacerlo. Una cuestión diferente es si una comunidad lingüística o un grupo específico de hablantes cuentan con una institución que les proporcione orientación en el uso de la lengua para ciertas situaciones de habla.

En lo que se refiera específicamente a la lexicografía inglesa, esta se encuentra en una curiosa paradoja, pues no hay una instancia que le sirva de referencia; no obstante ello, tanto el aprendiente de inglés como el hablante de inglés tienen necesidad de orientación. Ambos intuyen que, a veces, su desempeño lingüístico falla. De hecho, Peters (2006) resalta la profusión de guías de orientación lingüística que están a disposición del hablante nativo de inglés. En relación con los aprendientes, dichas obras también existen, como, por ejemplo, 50 common errors (Marsden, 2008) y Common Errors in English (Walter y Woodford, 2015). Tales obras existen porque tanto el hablante nativo como el aprendiente buscan orientación.

\section{La evaluación del desempeño equivocado en la lengua meta}

La evaluación del desempeño equivocado está en directa relación con la noción de error; así, se suele asociar el error a la dimensión gramatical. Metzler Lexikon Sprache (MLSp, 2010, s.v. Grammatik) define gramática como "descripción coherente de los modelos [sc. de construcción] y de las regularidades [sc. de una lengua] con fines didácticos, normativos o científicos". A partir de esta definición, una construcción como *El principal es que se logren resultados es un error pues, en español, los adjetivos antepuestos por un artículo exigen el artículo neutro lo (lo principal es que se logren resultados); igualmente es también un error escribir *La paciencia és una virtud en función de que los monosílabos no se acentúan en español. En cuanto al inglés, *I was living in France, but I left in 2002 (Marsden, 2008, p. 78) y *Let's choose other song (Walter y Woodford, 2015, p. 41) son errores. En el primer caso, para contrastar pasado y presente, se usa used to (I used to live in France, but I left in 2002). En el segundo caso, other se usa con sustantivos en plural, mientras que los sustantivos singulares llevan another (Let's choose another song).

En la lingüística aplicada que se preocupa con el aprendizaje de lenguas meta, Longman Dictionary of Language Teaching $\&$ Applied Linguistics (LoAppL, 2010) define error como

(en el habla o la escritura de un aprendiente de segunda lengua o de lengua extranjera) el uso de una forma lingüística (como, por ejemplo, una palabra, un ítem gramatical, un acto de habla, etc.) que se emplea de una forma tal que una persona que habla con fluidez o un hablante nativo de la lengua considera como equivocado o como un aprendizaje incompleto. (LoAppL, 2010, s.v. error)

En resumen, se puede afirmar que no existe en principio una oposición conceptual entre la definición de MLSp (2010) y la de LoAppL (2010). Cada vez que se juzge como incorrecta una forma o una secuencia de palabras, porque dicha forma o secuencia no condice con el modelo ejemplar de la lengua, este hecho se calificará como un potencial error.

No obstante, en el seno del aprendizaje de lenguas extranjeras se le ha dado más importancia al uso que a la gramática. Sobre este particular, Canale (1995, p. 35) añade que "Existen reglas de uso sin las cuales las reglas gramaticales resultarían inútiles"; estas reglas de uso constituyen, a su vez, una competencia en el uso. En efecto, junto con evaluar la propiedad gramatical de un enunciado 
(su gramaticalidad), Canale (1995) observa que también se deben llevar en cuenta las condiciones de cómo se emplean las formas lingüísticas al juzgar una expresión. Tales condiciones corresponden a la dimensión pragmática del acto de hablar, que siempre ocurre en "el aquí y el ahora". Es indudable que un diccionario monolingüe de aprendientes no es capaz de compilar hechos del "aquí y ahora". Por eso, este tipo de instrumento se restringe a dar orientaciones sobre cómo la lengua se usa efectivamente en la norma ideal.

\section{Los diccionarios monolíngües de aprendientes}

Borba y Bugueño (2019) consideran que todo diccionario termina ejerciendo una función pedagógica. En atención a su naturaleza de diccionario pedagógico, un diccionario monolingüe de aprendientes se diferencia de otras clases de diccionarios porque abarca dos factores: el nivel de dominio de la lengua extranjera de los estudiantes a quienes se dirige la obra (lo que ya se aprendió) y sus necesidades de aprendizaje provenientes del programa de trabajo para desarrollar el siguiente nivel de dominio (Borba y Bugueño, 2019, p. 1019).

El carácter pedagógico de los diccionarios monolingües de aprendientes también abarca la orientación en el uso de la lengua, pues el anhelo normativo corresponde justamente a una de las necesidades de aprendizaje que los autores mencionan. Concomitantemente, nuestras investigaciones en el área de la lexicografía monolingüe de aprendientes nos permitieron constatar que muchos diccionarios monolingües de inglés como lengua extranjera contienen notas con orientación en el uso de la lengua exactamente en ámbito del marco teórico que se presenta aquí, si bien se suele afirmar que en la lingüística inglesa la orientación acerca del uso de la lengua no es una cuestión aparentemente prioritaria. Claramente, esa clase de obras sí considera la noción de error. Mugglestone (2011, p. 70 y ss.) subraya que la lexicografía inglesa en su totalidad es una lexicografía descriptiva, puesto que refleja la norma real al amparo de la evidencia empírica (corpus). Al mismo tiempo, la autora identifica también la existencia de un fenómeno llamado autoridad legitimada [authoritativeness], que guarda relación con la posibilidad de orientar con tal de que dicha orientación esté fundamentada y no corresponda a la prescripción ex nihilo.

En el caso de los diccionarios monolingües de inglés como lengua extranjera, esta fundamentación teórica corresponde alos corpus en los que se apoyan, tales como el World English Corpus, de Macmillan; Cambridge English Corpus, de Cambridge; y Longman Corpus Network, de Pearson Longman. Cada uno de estos corpus tiene un subcorpus formado por producciones de aprendientes de inglés cuyos datos sirven de base para que los diccionarios monolingües de aprendientes de estas editoriales ofrezcan orientaciones relativas a determinadas formas producidas erróneamente. A la luz de lo expuesto hasta aquí, está claro que la detección del error se hace en función de la evidencia empírica que los corpus del inglés ofrecen (tanto el corpus de hablantes nativos como el de aprendientes). La norma real, por lo tanto, se toma como referencia para la orientación; de esta forma, se cumple la aserción de Mugglestone (2011) en el sentido de que es posible orientar bajo la premisa de que la fuente de orientación cumpla con el requisito de la autoridad legitimada (authoritativeness).

Constituye una verdadera paradoja que la metalexicografía anglosajona no se haya pronunciado sobre la orientación en el uso de la lengua presente en diccionarios monolingües de inglés como lengua extranjera, sobre todo si se considera todo lo que ha invertido en establecer parámetros básicos relativos al diseño de esta clase de diccionarios. Por lo que se refiere a la teoría, Rundell (2008, pp. 221-223) sintetizó muy bien dos principios básicos que rigen hasta este momento la compilación y evaluación de diccionarios monolingües de aprendientes: a) la descripción de la lengua se debe amparar en evidencia empírica; y b) las informaciones se deben presentar de acuerdo con las necesidades y habilidades lingüísticas del usuario a quien se dirige la obra.

Al observar los principios citados por Rundell (2008) en la práctica, la mayor parte de los diccionarios monolingües de inglés como lengua 
extranjera incluyen también informaciones de carácter normativo -dimensión claramente desconsiderada por la teoría-; en definitiva, la práctica abarca una dimensión sobre la que la teoría hasta ahora no se ha pronunciado. Extraña que tal dimensión sea tan evidente en una tradición que no ha tenido nunca una instancia orientadora oficial y que deja entrever que la descripción de la lengua es su rasgo preeminente.

La clase de orientación en el uso de la lengua que está presente en los diccionarios monolingües de aprendientes se puede representar de la siguiente manera en la Figura 1.

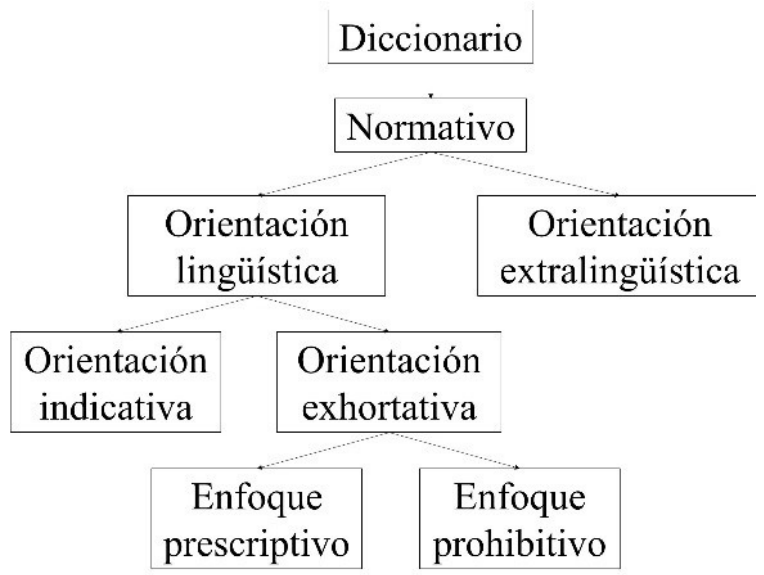

Figura 1. Tipos de orientación lingüística. Fuente: elaboración propia.

La orientación lingüística significa llamar la atención en relación con un determinado fenómeno de la lengua. Dicha orientación se subdivide en orientación indicativa y orientación exhortativa. La orientación indicativa se refiere a la simple descripción de un fenómeno (diferencias diatópicas, por ejemplo) sin que tal fenómeno constituya per se un eventual desempeño errado. En el caso de la orientación exhortativa, existe una llamada de atención manifiesta en relación con un fenómeno que requiere atención, pues puede constituir o constituye de hecho un error. En esta segunda modalidad, se reconocen dos sub-modalidades: una de ellas, la orientación exhortativa prescriptiva, corresponde a una orden clara y directa para seguir una instrucción; la otra, la orientación exhortativa prohibitiva, insta al aprendiente a no proceder lingüísticamente de una manera determinada.

Se analizaron los siguientes diccionarios: Cambridge Essential English Dictionary (CaEssD, 2011); Collins Cobuild Essential Dictionary (CCEssD, 2011); Longman Dictionary of Contemporary English (LoCD, 2014); Longman Basic Dictionary of American English (LoDAmE, 1999); Longman WordWise Dictionary (LoWWD, 2008); Macmillan English Dictionary for Advanced Learners (MacAD, 2007); Oxford Advanced Learner's Dictionary (OxALD, 2010); Oxford Essential Dictionary (OxEssD, 2012); y MerriamWebster's Advanced Learner's English Dictionary (WebALD, 2008). En las tablas 1, 2 y 3, se describen la orientación indicativa, la orientación prescriptiva exhortativa y la orientación prescriptiva prohibitiva, presentes en los diccionarios objeto de análisis.

\section{Análisis}

La evaluación de los ejemplos permite comprobar que todas las modalidades de orientación están presentes en la muestra compilada. Un rasgo común a todas ellas es la disposición de las informaciones en poscomentarios, esto es, en un bloque de texto al final del artículo léxico (Farias (2011) para más detalles sobre el poscomentario). Aunque esta es la posición más empleada, no siempre estos comentarios ad hoc ocupan este espacio, como sucede, por ejemplo, con algunos poscomentarios en PRob (2009, s.v. donner), denominados comentarios mediales internos por esta razón.

A fin de obtener el debido efecto de saliencia, los diccionarios evaluados emplean indicadores estructurales lingüísticos y no lingüísticos variados [Strukturanzeiger] (Engelberg y Lemnitzer, 2004, p. 134) para destacar cada una de las modalidades de orientación. Dichos sistemas abarcan desde el empleo de mayúscula asociada a diversas etiquetas (PRONUNCIATION, USAGE, GRAMMAR, LANGUAGE HELP, WHICH WORD?) hasta opciones no lingüísticas, tales como la utilización de un ícono ( i ) o de la tachadura de ejemplos considerados agramaticales. 
Tabla 1. Orientación indicativa.

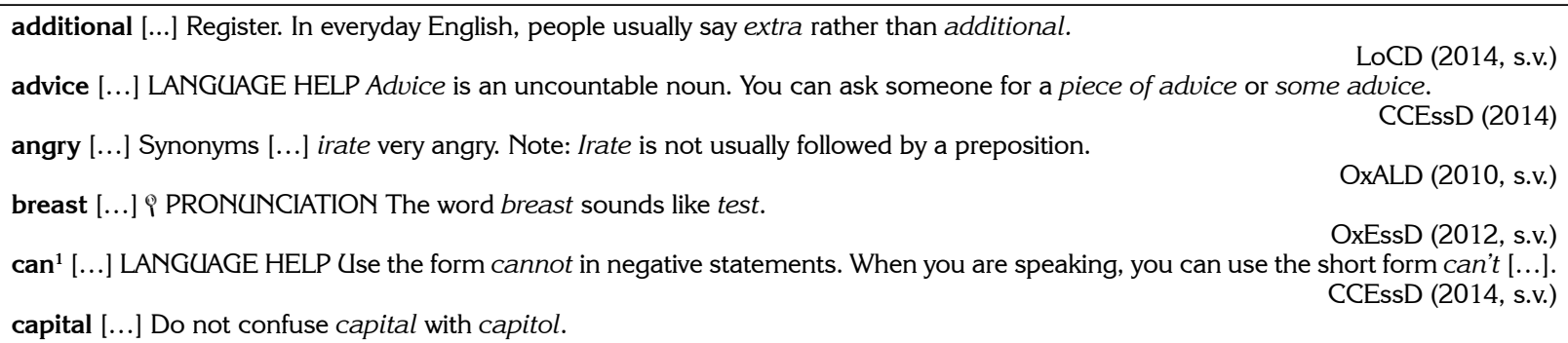

WebALD (2008, s.v.)

cleanse [...] usage The verbs clean and cleanse both mean "to make (something or someone) clean [...]". Cleanse usually refers to making the body or part of the body clean [...]. It can also refer to making a person's mind, soul, reputation [...]. Clean is more common than cleanse and its use is less specific.

WebALD (2008, s.v.) customer [...] LANGUAGE HELP When you buy something from a shop, you are a customer. When you use a service, you are a client.

CCEssD $(2014$, s.v. $)$

depend [...] Grammar. In informal English, it is quite common to say depend rather than depend on before words like that, how or whether [...]. In formal written English, depend should always be followed by on or upon [...].

OxALD (2010, s.v.)

different [...] Grammar. Prepositions with different. In American English, people also say different than. In British English, people also say different to $[\ldots]$.

floor [...] LANGLAGE HELP In British English, the ground floor of a building is the floor that is level with the street. The floor on the next level is called the first floor. In American English, the first floor is the floor that is level with the street, and the next floor up is the second floor.

have $^{1}[$...] LANGUAGE HELP When you are speaking, you can use the short form I've for I have and hasn't for has not.

CCEssD $(2014$, s.v. $)$

CCEssD $(2014$, s.v. $)$

hear [...] LANGUAGE HELP hear or listen? Use hear to talk about sounds that you notice when they reach your ears. I heard a noise downstairs. Use listen when you are paying attention to something you can hear. He turned on the radio and listened to the news.

lawyer [...] Differences between British and American English: lawyer

CCEssD (2014, s.v.)

In both the UK and the US, lawyer is the general word for a trained legal adviser. In the UK, a lawyer who usually works in an office but may also work in some courts of law is called a solicitor. Lawyers who do most of their work representing people in the court trials are called barristers in England and advocates in Scotland. In both the UK and the US, counsel is the formal word for a lawyer who is representing people in the court, and in a US court, you might call them counselor. A lawyer in the US is also sometimes referred to as an attorney, especially in formal speech or official letters.

$\operatorname{MacAD}(2007$, s.v. $)$

like $[. .$.$] usage The use of like as a conjunction is regarded by some people as an error. It occurs mainly in speech and informal writing.$

nought $[\ldots]$ PRONUNCIATION You pronounce nought like 'sort'.

WebALD (2008, s.v.)

professor [...] Differences between British and American English: Professor

OxEssD (2012, s.v.)

In the UK, a professor is a university teacher of the highest level, who is usually in charge of the other teachers of their subject. In the US, a professor is any full-time teacher at a university.

MacAD (2007)

sensitive [...] Sensible describes the reasonable way in which you think about things or do things: It wouldn't be sensible to start all over again now

Sensitive describes the emotional way in which you react to things: I didn't realize she was so sensitive about her work.

shop [...] usage

MacAD (2007)

In U.S. English, store is more common than shop. When shop is used, it is usually for particular types of small businesses that sell one kind of product or service. Store is used for both small and large businesses, especially ones that sell many kinds of goods and services. In British English store is only used for large businesses that sell many kinds of goods and services and for a few types of smaller businesses that sell equipment.

WebALD (2008, s.v.) swim $^{1}[\ldots]$ USAGE When talking about swimming as an activity that you do, you say go swimming: I go swimming two or three times a week.

that $[\ldots]$ usage That in this sense is often omitted in informal English [...]. When it is the subject of a verb, however, it is always included [...]. 
Tabla 2. Orientación prescriptiva exhortativa.

capital [...] LANGUAGE HELP Note that you must always use a capital letter with days of the week and month of the year.

CCEssD $(2014$, s.v. $)$

forget $[. .$.$] LANGUAGE HELP If you want to say that you put something somewhere and left it there, use the verb leave.$

high [...] LANGUAGE HELP When you are describing people, use tall. She was a tall woman.

CCEssD (2014, s.v.)

lend [...] Common mistake: lend and borrow

CCEssD (2014, s.v.)

Be careful not to confuse these two verbs. Lend means to give something to someone for a period of time. It was raining so she lent me her umbrella. Borrow means to use something that belongs to someone else and give it back later.

CaEssD (2011, s.v.)

strike $^{1}[\ldots]$ Hit is the more usual word, but when you talk about lightning (= the flashes of light that you see in the sky when there is a storm), you always use strike: The tree was struck by a lightning.

win [...]WHICH WORD? Be careful! You earn (not win) money by working.

OxEssD (2012, s.v.)

OxEssD (2012, s.v.)

Tabla 3. Orientación prescriptiva prohibitiva.

increase $^{2}[\ldots]$ Get it right: increase

Don't use increase of when you want to say what is increasing. Use increase $\underline{i n}$ : $\mathbf{X}$ Is gun ownership connected with the increase of violent crime? $\checkmark$ Is gun ownership connected with the increase in violent crime? [...] Use increase of with a number or percentage when you want to talk about the amount by which something increases: There has been an increase of nearly $30 \%$ in spending on hospitals.

MacAD (2007, s.v.)

information [...] 9 GRAMMAR Be careful! You cannot say 'an information'. You say some information or a piece of information: She gave me an interesting piece of information.

information [...] Get it right: information

OxEssD (2012, s.v.)

Information is an uncountable noun, so: it is never used in the plural, it never comes after an or a number: $\mathbf{x}$ Customers can find about products and services. $\checkmark$ Customers can find information about products and services. $\times$ TV helps people to get an impont information. $\checkmark T V$ helps people to get important information. $\times$ Their website provides many informations about courses you can take.$\checkmark$ Their website provides a lot of information about courses you can take. $\checkmark$ Their website provides a great deal of information about courses you can take.

depend $[\ldots]$ Common mistake: depend on something

MacAD (2007, s.v.)

Be careful to choose the correct preposition after depend. I might go -it depends on the weather. I might go- it depend of the weather. Imight go it depends from the weather.

discuss [...] Common mistake: discuss

CaEssD (2011, s.v.)

Discuss is not followed by a preposition. We discussed the plans for the wedding. We diseussed about the plans for the we can discuss something with someone.

lend [...] Common mistake: lend and borrow

CaEssD (2011, s.v.)

Be careful not to confuse these two verbs. Lend means to give something to someone for a period of time. It was raining so she lent me her umbrella. Borrow means to use something that belongs to someone else and give it back later.

CaEssD (2011, s.v.) library [...]WHICH WORD? Be careful! You cannot buy books from a library. The place where you buy books is called a bookshop or a bookstore. spelled with only one 'o' and it is pronounced /lu:z/: XShe was afraid of adjective meaning 'not tight' or 'not firmly fixed'. It is spelled with a double 'o' and is pronounced differently, / lu:s/: Christina was dressed in shorts and a loose cotton shirt.

know $^{1}$ [...] GRAMMAR Use know in simple sentences, not progressive tenses. X Don't say 'I am knowing'

MacAD (2007, s.v.)

please $^{1}[\ldots]$ GRAMMAR You say Please sit down. XDon't say 'Please to sit down'

LoWWD (2008, s.v.)

LoWWD (2008, s.v.) 
En general, es posible constatar que existe una correspondencia entre la clase de orientación y su formulación, es decir, hay una relación entre lo que se desea destacar y la forma de representar la información, como s.v. customer (CCEssD, 2014). En otros casos, como s.v. win (OxEssD, 2012), no obstante, la formulación es un poco más compleja. Es oportuno recordar que la orientación exhortativa corresponde a dos modalidades, como ya se mencionó ad supra. La orientación exhortativa prescriptiva corresponde a una modalidad de instrucción para que se ejecute una tarea lingüística de una determinada manera (ihazlo así!). La orientación exhortativa prohibitiva, por otra parte, es una instrucción para que no se ejecute una tarea de una determinada manera (ino lo hagas así!). En el caso de (to) win, la instrucción es confusa, porque el poscomentario no se refiere a (to) win, sino que al verbo (to) earn. Todo poscomentario debe referirse siempre al signo lema. Además, en este caso concreto, el poscomentario resalta que el sustantivo money "exige" un determinado verbo; se trata, por lo tanto, de un patrón colocacional. Considerando que una característica distintiva de este fenómeno léxico es su bajo grado de predicción por parte del aprendiente, su explicitación necesita ser muy clara. La negación del verbo (to) win como miembro de la colocación (not win) de money no es un mecanismo eficiente (Bugueño y Borba (2019) para la explicitación de patrones colocacionales). En este mismo ámbito, cabe cuestionarse el hecho de que solo el verbo (to) earn recibió un resalte tipográfico en cursiva; para reforzar el binomio el sustantivo money también habría tenido que ser resaltado de alguna forma.

El análisis reveló que una parte importante de los artículos con poscomentarios de orientación de uso de la lengua corresponde a la orientación indicativa. Esta clase de orientación se demostró bastante variada. Hay casos en que los diccionarios destacan designaciones diferentes o preferencias léxicas para una dada entidad léxica según variación diatópica, como s.v. floor (CCEssD, 2014), lawyer (MacAD, 2007) y shop (WebALD, 2008). En otros casos la orientación indicativa se convierte en un poscomentario semántico de sinonimia discriminativa, como s.v. professor (MacAD, 2007); de la misma forma, el comentario sirve también para destacar patrones sintácticos, estén estos relacionados o no a una distinción diatópica, como s.v. angry (OxALD, 2010), depend (OxALD, 2010), different (LoCD, 2014) y swim ${ }^{1}$ (LoWWD, 2008). Se encontraron también casos de orientación indicativa fonética, como s.v. breast (OxEssD, 2012) y nought (LoWWD, 2008).

Como síntesis parcial cabe destacar que la orientación indicativa no tiene otro objetivo que informar al aprendiente sobre un dado hecho de norma. Su explicitación sigue como patrón común una descripción formulada en términos simples que se abstiene claramente de evaluar el fenómeno descrito. Este cuidado se torna evidente hasta en el poscomentario s.v. like "The use of like as a conjunction is regarded by some people as an error. It occurs mainly in speech and informal writing" (WebALD, (2008). Es perceptible que el hedge "by some people" no solo limita el valor universal de la afirmación, sino que también constituye una indicación del valor relativo del fenómeno en cuestión, circunscrito, además, al registro oral e informal.

En lo que concierne a la orientación exhortativa prescriptiva, esta se encuadra claramente como un acto perlocutivo (Crystal, 2003a, pp. 121-122). Se puede afirmar que el aprendiente percibe y acepta la orden asumiendo que el diccionario posee authoritativeness, para emplear el término usado por Mugglestone (2011, p. 80). En función de ello, las órdenes están claramente formuladas.

Desde el punto de vista de la estructuración de los enunciados del poscomentario, su redacción se caracteriza por la presencia de expresiones imperativas, tales como "you must" (CCEssD, 2014, s.v. capital) y "be careful" (CaEssD, 2011, s.v. lend). Al igual que en el caso de (to) win comentado ad supra, s.v. high (CCEssD, 2014) se presenta también un patrón colocacional (tall woman). La referencia a este patrón se hace sobre la Leseart "elevado sobre la tierra", común a high e tall. Empleándose el ya tradicional estilo de la whole sentence definition (Hartmann y James, 2001, s.v. definition style), la sentencia performativa "When you are describing people, 
use tall" constituye una instrucción clara sobre los miembros del patrón colocacional.

La orientación exhortativa prohibitiva, por otra parte, es el caso más claro de instrucción. En primer lugar, cabe destacar el empleo masivo de etiquetas de orientación: "Get it right", "Be careful" y "Common mistake". Nótese que estas etiquetas están formuladas sobre la base de implicaturas convencionales [conventional implicature] (SILGl, 2019, s.v.). Esto significa que, si hay una manera correcta de "hacerlo bien", es porque hay otra equivocada; si es necesario "ser cuidadoso" es porque hay estructuras lingüísticas que son una trampa [piège], como tan acertadamente las denomina la lingüística francesa. Si hay "errores comunes" es porque muchos aprendientes de inglés los cometen.

En segundo lugar, cabe destacar que la propia instrucción está redactada en imperativo negativo: "Don't use" (MacAD, 2007, s.v. increase ${ }^{2}$ ) "You cannot say" (OxEssD, 2012, s.v. information) o "Don't say" (LoWWD, 2008, s.v. please1).

En tercer lugar, es posible advertir una clara tendencia a la recursividad, ya típica, por ejemplo, en la lexicografía monolingüe del alemán como lengua extranjera (Bugueño, 2019, p. 81) y cuyo objetivo es maximizar el efecto de saliencia. La recursividad es compositiva; así, por ejemplo, como s.v. information (MacAD, 2007) y depend (CaEssD, 2011), sigue a la instrucción en imperativo negativo un ejemplo con la estructura correcta (subrayada o no). A continuación del ejemplo correcto viene un segundo ejemplo con el uso errado debidamente tachado; además, cada ejemplo va precedido por un indicador estructural no lingüístico de aprobación $(\checkmark)$ o reprobación $(\mathbf{X})$. Evidentemente, todo este conjunto de instrucciones es complementario a las etiquetas y a las instrucciones ya descritas anteriormente. A pesar de que no en todos los artículos se usa la totalidad de los mecanismos recursivos, por lo menos uno de ellos se activa.

No hay cómo dudar de la efectividad de estos procedimientos para ayudar a comprender de forma clara y unívoca cada uno de los fenómenos que los diccionarios tratan.

\section{Conclusiones}

En las páginas iniciales se mencionó que la lingüística inglesa como un todo se define a sí misma como una lingüística descriptiva. En la lexicografía esa tendencia aparentemente se mantuvo, sobre todo cuando la compilación de obras lexicográficas pasó a fundamentarse en la evidencia empírica que los corpus ofrecen. En CCLD (2003, p. v) se enfatiza que "Todas las afirmaciones que Cobuild hace están basadas en el examen de la lengua inglesa en uso". En relación con los ejemplos, se afirma también que "están tomados de este corpus [i.e. The Bank of English] y representan la lengua real en uso [destacado en el original]". Ya en CCAD (2009, p. x) y a propósito de un enlace para una página de internet, se observa una mudanza de perspectiva cuando se afirma que la página "les ofrece a los aprendientes una forma rápida y simple de comprender el uso correcto" (CCAD, 2009). Es evidente que este cambio lo asumen no solo los diccionarios de la serie Collins Cobuild, sino que también todos los diccionarios monolingües de inglés como lengua extranjera. En la selección hecha para este trabajo, se tomó en cuenta que las obras reflejaran el mayor espectro posible de aprendientes en términos de su competencia; por ello, se seleccionaron diccionarios compilados para aprendientes con nivel de competencia entre A2 y B1 y para cuyas necesidades las editoriales ofrecen el Essential Dictionary. Al otro extremo están los aprendientes con nivel de competencia entre B2 y C2 y para los que las editoriales ofrecen el Advanced Learner's Dictionary. El análisis demostró que hay orientación en el uso de la lengua para todo el espectro de aprendientes.

La explicitación de la orientación en el uso de la lengua parece obedecer a la asunción de que el desempeño lingüístico del aprendiente requiere una constante retroalimentación que le permita alcanzar el "uso correcto", empleando las palabras de CCAD (2009). Esta misma explicitación contribuye a la llamada autonomía en el aprendizaje; de esta forma, el diccionario cumple con la doble función de ofrecer una vera imaginem linguae, por un lado, y, por el otro, los lapsus ad corrigenda. 
Si el objetivo final de la enseñanza y aprendizaje de una lengua extranjera es que un individuo consiga articularse lingüísticamente de manera eficiente, dicha eficiencia se encuentra relacionada también con el uso de formas y estructuras lingüísticas gramaticales y aceptables. Tener dominio de una lengua extranjera significa igualmente dar atención a la corrección en el uso de la misma y la lexicografía monolingüe de aprendientes del inglés parece haber comprendido ejemplarmente esto.

\section{Referencias}

Alarcos, E. (1994). Gramática de la Lengua Española. Espasa.

Borba, L. y Bugueño, F. (2019). Passado, presente e futuro dos dicionários de aprendizes. Domínios de Lingu@ gem, 13(3), 1018-1040. https://doi.org/10.14393/ DL39-v13n3a2019-9

Bugueño, F. (2019). A propósito de tres diccionarios de DaF: Sobre el Estado de la Lexicografía de Aprendices del Alemán. Pandaemonium Germanicum, 22(36), 67-96. https://doi.org/10.11606/1982-8837223667

Bugueño, F. y Borba, L. (2019). As combinatórias léxicas e o ensino de língua espanhola: o quanto ajudam os dicionários bilíngues português / espanhol? Hispanic Research Journal, 20(3), 214-238. https://doi.org/1 $\underline{0.1080 / 14682737.2019 .1651572}$

CaEssD. (2011). Cambridge Essential English Dictionary. CUP.

Canale, M. (1995). De la competencia comunicativa a la pedagogía comunicativa del lenguaje. In M. Llobera (Coord.). Competencia comunicativa. Documentos básicos en la enseñanza de lenguas extranjeras (pp. 63-81). EDELSA.

CCAD. (2009). Collins Cobuild Advanced Dictionary. Heinle.

CCEssD. (2014). Collins Cobuild Essential Dictionary. HarperCollins.

CCLD. (2003). Collins Cobuild Learner's Dictionary. Concise Edition. HarperCollins.

Coseriu, E. (1992). Einführung in die Allgemeine Sprachwissenschaft. Francke.

Crystal, D. (2003a). The Cambridge Encyclopedia of Language. CUP.

Crystal, D. (2003b). English as a global language. Cambridge: CUP.
Engelberg, St. y Lemnitzer, L. (2004). Lexikographie und Wörterbuchbenutzung. Stauffenburg.

Farias, V. (2011). Considerações preliminares sobre o pós-comentário na microestrutura de dicionários semasiológicos. Revista Virtual de Estudos da Linguagem, 9, 109-139. www.revel.inf.br/files/ artigos/revel 17 consideracoes preliminares.pdf.

Hartmann, R. y James, G. (2001). Dictionary of lexicography. Routledge.

LoAppL. (2010). Richards, J. C. y Schmidt, R. Dictionary of Language Teaching $\&$ Applied Linguistics. Pearson Education.

LoCD. (2014). Longman Dictionary of Contemporary English. Pearson.

LoDAmE. (1999). Longman Basic Dictionary of American English. Pearson.

LoWWD. (2008). Longman WordWise Dictionary. Pearson.

MacAD. (2007). Macmillan English Dictionary for Advanced Learners. Macmillan.

Marsden, B. (2008). 50 Common Errors. A Practical Guide for English Learners. Merriam-Webster.

MLSp. (2010). Glück, H. (Hrsg.). Metzler Lexikon Sprache. J.B. Metzler.

Moreno de Alba, J. (1992). Minucias del lenguaje. FCE.

Moreno de Alba, J. (1993). El español en América. FCE.

Mugglestone, L. (2011). Dictionaries. A very short Introduction. OUP.

Nava, A. (2017). Errors and learning/teaching English as a second/foreign language: an exercise in grammaticology. Altre modernitá, 17, 79-97. https:// doi.org/10.13130/2035-7680/8304

OxALD. (2010). Oxford Advanced Learner's Dictionary. OUP.

OxEssD. (2012). Oxford Essential Dictionary. For elementary and pre-intermediate learners of English. OUP.

OxLing. (1997). Matthews, P. H. Oxford Concise Dictionary of Linguistics. OUP.

Peters, P. (2006). Prescription and description. In B. Aarts y A. McMahon (Ed.). The Handbook of English Linguistics (pp. 759-780). Blackwell Publishing.

PRob. (2009). Petit Robert. Dictionaire de la langue française. Le Robert.

Rundell, M. (2008). Recent trends in English Pedagogical Lexicography. In Th. Fontenelle (Ed.). Practical Lexicography. A reader (pp. 221-243). OUP. 
SILGI. (2019). Summer Institut of Linguistics. SIL Glossary of linguistic terms. https://glossary.sil.org/term.

Walter, E. y Woodford, K. (2015). Collins Common Errors in English. HarperCollins.

WebALD. (2008). Merriam-Webster's Advanced Learner's English Dictionary. Merriam-Webster.
Zanatta, F. (2017). A norma linguística e seu reflexo em dicionários de língua portuguesa. Novas Edições Acadêmicas/OMNIScriptum.

\section{(c) (i) $\odot$}

